\title{
Performance, carcass characteristics and meat physico-chemical properties of broiler chickens fed graded levels of supplemental ascorbic acid
}

\author{
Ogunwole, O. A., Oso, Y. A. A., Omotoso, R. R., Majekodunmi, B. C., Ayinde, B. O. and \\ Oikeh, I. \\ Animal Nutrition Unit, Department of Animal Science, University of Ibadan, Ibadan, Nigeria \\ Corresponding Author's E-mail Address:droaogunwole@gmail.com
}

\begin{abstract}
A 56-day trial to evaluate the performance, carcass characteristics and meat physico-chemical properties of broiler birds fed graded inclusion of supplemental ascorbic acid (AA) was undertaken using 270 one-day old Arbor acre broiler chicks. Basal starter and finishers diets (T1) contained $0 \% \mathrm{AA}$ (control); while diets T2, T3, T4, T5 and T6 were supplemented with $0.1,0.2$, $0.3,0.4$ and $0.5 \%$ AA respectively. Performance data indicated similar $(p>0.05)$ daily and total feed intake by birds. Feed conversion ratio $(3.04,2.86,2.85,2.74,2.77$ and 2.69 for birds on diets $\mathrm{T} 1, \mathrm{~T} 2, \mathrm{~T} 3, \mathrm{~T} 4, \mathrm{~T} 5$ and T6 respectively) were also similar ( $p>0.05)$. However weight gain and final body weight were significantly higher $(p<0.05)$ for birds on AA supplementation compared with control. Correlation of graded AA inclusion and weight gain of chickens was positive $(r=0.50)$ and significant $(p<0.05)$. Regression of weight gain $(\mathrm{kg})$ on graded AA supplementation indicated $\left(R^{2}=0.2531\right)$ a minimum of $1.67 \mathrm{ppm}$ dietary $A A$ requirement for growth. Abdominal fat, eviscerated weight as well as weight of heart varied significantly $(p<0.05)$. Other carcass characteristics, organ indices and meat physico-chemical indices were not significantly different ( $p>0.05)$. Supplemental dietary AA was implicated in growth and improved color of broiler meat in this study.
\end{abstract}

Keywords: Supplemental vitamin C, Stress mitigation, Abdominal fat, Basal starter and finishers diets. Broiler performance

\section{INTRODUCTION}

Commercial broilers are economic agricultural field production units in which the objective is to maximize field performance (Lohakare et al., 2005). The main intention of modern poultry nutrition is to fully utilize the genetic potential of birds by producing complete diets covering all known nutrient requirements according to the species, egg, production category and performance level.

The stress of high ambient temperature in the tropics may negatively influence the performance of broiler chickens by reducing feed intake, live weight gain and feed efficiency. Environmental stress causes oxidative stress and impairs antioxidants status in vivo (Halliwell and Gutteridge, 1989; Klasin, 1998; Sahin, et al., 2001).

Several methods to alleviate the negative effects of high environmental temperature on performance of poultry have been documented (Sahin et al., 2001; Lohakare et al., 2005; Majekodunmi et al., 2012;
Ogunwole et al., 2013). Studies (Kafri and Cherry, 1984; Njoku, 1986; McDowell, 1989; Mowat, 1994; Sahin et al., 2003) have shown that antioxidant nutrient supplementation, especially vitamin C, E, and $A$, zinc and chromium, can be used to mitigate the negative effects of environmental stress.

Though, chickens can synthesis vitamin $\mathrm{C}$, the synthesis was reported to be inadequate under stressful conditions such as low or high environmental temperature, high humidity, high production rate and parasite infestation (Sykes, 1978; McDowell, 1989).

Previous reports have revealed the beneficial effect of vitamin $\mathrm{C}$ supplementation on growth rate, egg production, egg shell strength and thickness in stressed laying hens and broilers (Sykes, 1978; Pardue and Thaxton, 1986; Sahin and Kucuk, 2001). However, the full practical relevance and actual level of supplementation remained a subject of extensive discourse (Ogunwole et al., 2012). The present study was undertaken to evaluate the performance, 
carcass characteristics and meat physico-chemical properties of broiler chickens fed graded dietary supplement of AA.

\section{MATERIALS AND METHODS}

Two hundred and seventy, 1 - day old Arbor acre broiler chicks, of average weight $41.54 \pm 2.23 \mathrm{~g}$ ) were assigned to six treatments consisting of 45 birds per treatment. Each treatment comprised a triplicate of 15 birds each. The dietary vitamin $\mathrm{C}$ levels were 0 , 100, 200, 300, 400 and 500ppm respectively. Formulated basal starter and finishers' diets composition is shown in Table 1. Recorded environmental temperature in the experimental period ranged from 28 to $30^{\circ} \mathrm{C}$. Birds were served their respective diets with water offered ad libitum.

Other routine medications and vaccinations for broiler chicks were observed (Oluyemi and Roberts, 2000)

Body weight and feed intake were recorded weekly and the feed efficiency was calculated. At day 56, two birds per treatment with average weight closest to the mean of their group weight were purposively selected, tagged, starved of feed overnight and slaughtered. The final weight of birds, bled, defeathered, carcass and eviscerated weights were recorded. They were scalded manually and carefully dissected. The external offal (head, neck and shank); primal cuts (wings, breast, back, thigh and drumstick); and internal offal (liver, heart, abdominal fat, spleen and intestine) were weighed and the weights related to the live weight. Thermal shortening of the prima cuts were determined (Awonrin and Ayoade, 1992). Cooking and chilling losses were according to Mahendraker et al. (1988). Water holding capacity was by the procedure of Suzuki et al. (1991). Meat sensory evaluation was undertaken (Omojola and Adesehinwa, 2007). Meat samples for proximate determination were obtained via removal of $20 \mathrm{~g}$ from each of the primal cuts (thigh, breast and drumstick) which were then homogenized and ovendried. Proximate composition of meat in duplicate (Horwitz, 1990) was determined according to AOAC (1990). Carcass and meat pH were obtained with the use of $\mathrm{pH}$ meter by a direct probe and thrusting into the breast muscle. The design of the experiment was a completely randomized design.

Table 1: Gross composition (\%) of basal starter and finishers' diets fed to Broiler chickens

\begin{tabular}{|c|c|c|}
\hline Ingredients & $\begin{array}{l}\text { Starter diet } \\
0 \text { to } 3 \text { weeks }\end{array}$ & $\begin{array}{l}\text { Finisher diet } \\
4 \text { to } 8 \text { weeks }\end{array}$ \\
\hline Maize & 52 & 51 \\
\hline Soyabean meal & 35 & 25 \\
\hline Palm oil & 2.5 & 2.5 \\
\hline Wheat offal & 7.23 & 17.73 \\
\hline Oyster shell & 1.0 & 1.0 \\
\hline DCP & 1.5 & 1.5 \\
\hline Salt & 0.25 & 0.25 \\
\hline Lasalocid & 0.06 & 0.06 \\
\hline Premix ${ }^{*}$ & 0.25 & 0.25 \\
\hline Methionine & 0.15 & 0.15 \\
\hline Lysine & 0.06 & 0.06 \\
\hline Ascorbic acid & - & - \\
\hline Total & 100 & 100 \\
\hline \multicolumn{3}{|l|}{ Calculated nutrient } \\
\hline Crude Protein (\%) & 22.94 & 19.5 \\
\hline $\mathrm{ME}(\mathrm{kcal} / \mathrm{kg})$ & 3147 & 3145 \\
\hline \multicolumn{3}{|c|}{$\begin{array}{l}\text { ME - Metabolizable Energy; DCP - Dicalcium Phosphate; } \\
\text { Premix* - Vitamin A-10,000,000iu, Vitamin D3-2,000iu, Vitamin E-40,000mg, Vitamin K-2,000mg, Vitamin B1-1,500mg, } \\
\text { Vitamin B2-4,000mg, Vitamin B6-40,000mg, Vitamin B12-20mgr, Niacin-40,000mg, Panthothenic-10,000mg, Folic- } \\
\text { 1,000mg, Biotin-100mg, Choline Chloride-300,000mg, Manganese-80,000mg, Zinc-60,000mg, Iron-40,000mg, Copper- } \\
80,000 \mathrm{mg} \text {, lodine-800mg, Selenium-200mg, Cobalt-300mg, Antioxidant-100,000mg. }\end{array}$} \\
\hline
\end{tabular}

Statistical analysis: Data collected were subjected to analysis of variance (Assistat, 2012) and the means when significant were separated using
Duncan Multiple Range Test of the same statistical package. 


\section{RESULTS AND DISCUSSION}

Performance indices of broiler chickens fed graded dietary ascorbic acid (AA) are shown in Table 2 . The final weights $(\mathrm{kg})$ of birds' $(1.66,1.78,1.75,1.89$, 1.90 and 1.79 for birds on T1, T2, T3, T4, T5 and T6 respectively) were significantly different $(p<0.05)$. Weight gained $(\mathrm{kg})$ by the respective birds on $\mathrm{T} 1, \mathrm{~T} 2$, T3, T4, T5 and T6 on were 1.62, 1.74, 1.71, 1.85, $1.86,1.75$ which also varied significantly $(p<0.05)$. Final weight and weight gained by broilers fed 100 , 200 and $600 \mathrm{ppm}$ supplemental AA were similar $(p>0.05)$ to those on control but lower $(p<0.05)$ compared to those on other supplemental levels. The lower final weight and weight gained by birds on control diet suggested that endogenous synthesis of AA by birds was not enough to meet birds' requirement in the prevailing hot weather condition. This observation agreed with earlier reports (Raja and Qureshi, 2000; Oruseibio and Alu, 2006; Sabah et al., 2008; Onu, 2009;) of depressed weight gain in heat stressed birds fed diet without $A A$ supplementation. However, similarities $(P>0.05)$ in the values obtained for the control birds and those given diets supplemented with 100 and 200ppm AA could be due to inadequate levels of supplementation to effect any significant difference compared with the control. This observation conformed to the findings of Puron et al. (1994) and Sykes (1977) that no effect was obtained on performance and survivability in broiler birds fed diet supplemented with 200 ppm AA. The higher weight gained by birds fed $A A$ supplemented diet indicated ameliorative effect of supplemental AA on heat stressed birds which corroborated the findings of Kassim and Norziha (1995); Mckee et al. (1997); Sosnowka-Czajka et al. (2003); Bolu et al. (2004) Sabah et al. (2008); Sobayo et al., (2008) and Onu (2009) that supplemental AA improved weight gained by birds exposed to heat stress. The improved weight gain of birds on different levels of inclusion up to 400ppm before a decline in weight gain in birds fed 500ppm indicated that supplemental AA up to $400 \mathrm{ppm}$ was within the tolerable limits of birds and that inclusion at the rate of $500 \mathrm{ppm}$ exceeded tolerable limits of broiler birds. These observations underscored the reports of Onu (2009) that $150-450 \mathrm{mg} / \mathrm{kg}$ was a tolerable range for AA supplementation in the diets of broiler birds. However, the result contradicted other authors (Sifri et al., 1977; Pardue et al., 1985; Faria et al., 1999 and Sosnowka - Czajka, et al., 2005) who did not obtain any improved growth or weight gain in the supplemental groups.

Feed conversion ratio (FCR) obtained for birds were not significantly different $(p>0.05)$ among birds fed supplemental AA and the control. However, correlation of dietary AA and weight gain of chickens was positive $(r=0.50)$ and significant $(p<0.05)$. Regression of weight gain $(\mathrm{kg})$ on graded $A A$ supplementation (Figure 1) gave the regression equation $y=0.3299 x+1.671 \ldots \ldots \ldots \ldots \ldots \ldots\left(R^{2}=\right.$ 0.2531 ) which indicated a minimum of $1.67 \mathrm{ppm}$ dietary AA requirement for growth.

Supplemental AA had no significant ( $p>0.05$ ) effect on feed intake of broiler chickens. This finding agreed with the reports of Dale and Fuller (1980); Vathana et al. (2002); Oruseibo and Alu (2006); Sabah et al. (2008); Onu (2009). However, Villar-Patiño et al. (2002) reported that Vitamin C-supplemented diets resulted in lower feed consumption and lower rates of feed conversion. Lohakare et al. (2005) and Sosnowka - Czajka, et al. (2005) did not obtain improvement in feed conversion in broiler chickens due to vitamin C supplementation. However, this result contradicted other reports (Alisheikor, 1980; Njoku et al., 1990; Blaha et al., 2000; Onu, 2009) that vitamin $C$ supplementation significantly improved FCR.

Table 2: Performance characteristics of broiler chickens fed diets supplemented with graded levels of ascorbic acid

\begin{tabular}{|l|l|l|l|l|l|l|l|}
\hline Parameters & T1 & T2 & T3 & T4 & T5 & T6 & SEM \\
\hline Initial body weight. (kg) & 0.04 & 0.04 & 0.04 & 0.04 & 0.04 & 0.04 & \\
\hline Final body weight (kg) & $1.66^{\mathrm{b}}$ & $1.78^{\mathrm{ab}}$ & $1.75^{\mathrm{ab}}$ & $1.89^{\mathrm{a}}$ & $1.90^{\mathrm{a}}$ & $1.79^{\mathrm{ab}}$ & 0.04 \\
\hline Weight gain (kg) & $1.62^{\mathrm{b}}$ & $1.74^{\mathrm{ab}}$ & $1.71^{\mathrm{ab}}$ & $1.85^{\mathrm{a}}$ & $1.86^{\mathrm{a}}$ & $1.75^{\mathrm{ab}}$ & 0.04 \\
\hline Daily feed intake (kg) & 0.12 & 0.09 & 0.09 & 0.16 & 0.09 & 0.08 & 0.01 \\
\hline Total feed intake (kg) & 4.92 & 4.97 & 4.85 & 5.06 & 5.13 & 4.70 & 0.06 \\
\hline FCR & 3.04 & 2.86 & 2.85 & 2.74 & 2.77 & 2.69 & 0.05 \\
\hline
\end{tabular}




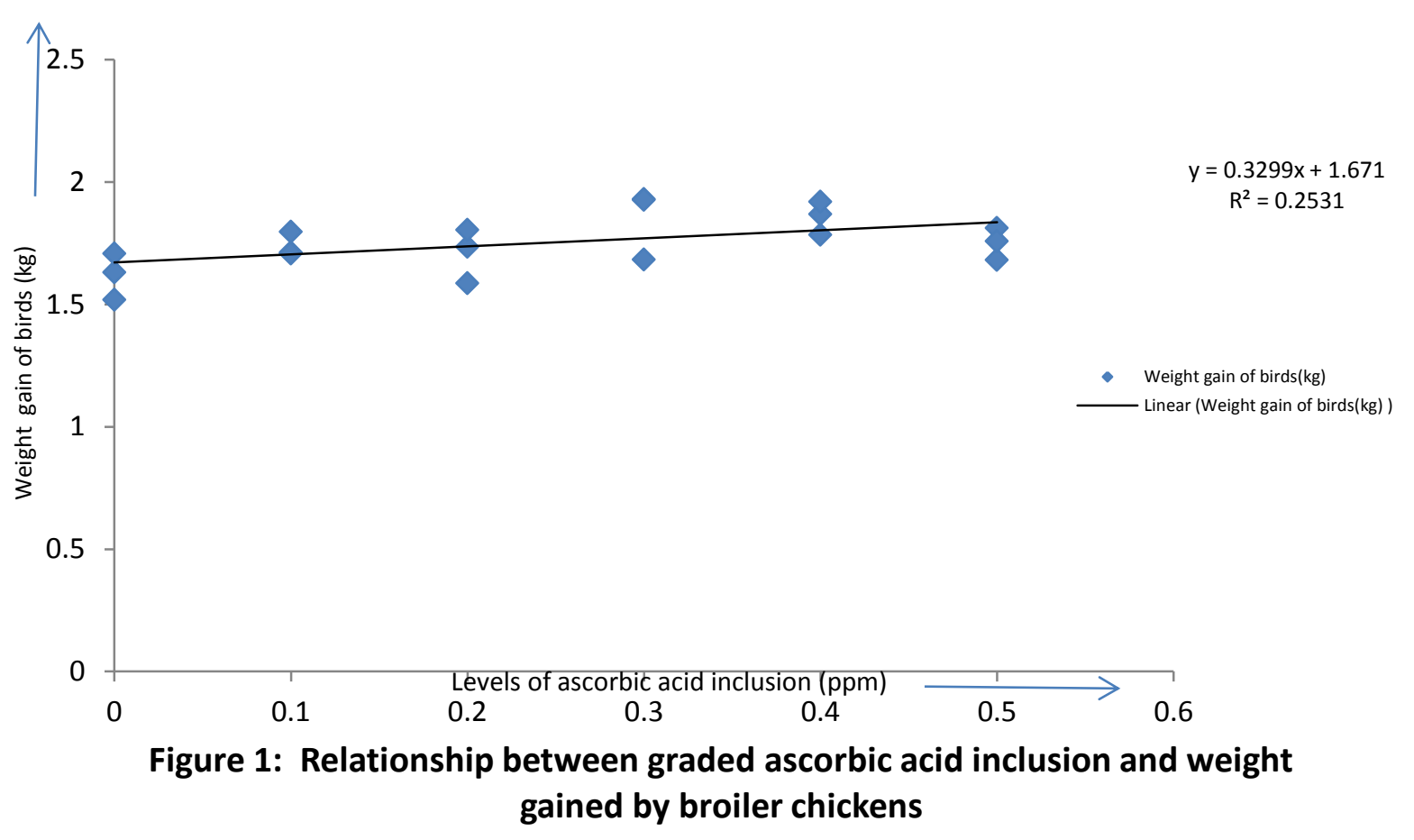

Carcass characteristics of broiler chickens fed graded levels of AA are shown in Table 3 . There were no significant $(p>0.05)$ differences in obtained bled, defeathered and carcass weights of broiler birds. Also, weights obtained for primal cuts (thigh, drumstick, wings, breast and back) were similar ( $p>0.05$ ) which contradicted earlier reports (Bonsembinate et al., 2002; Pisarski et al., 2003; Lohakare et al., 2004; Mbajiorgu et al., 2007; Ali et al., 2010) that dressing yield, thigh, breast and wing meat were higher in groups which received Vitamin C in drinking water compared to those on control. There were significant differences $(p<0.05)$ in the eviscerated, liver, heart and abdominal fat of broiler birds. Birds on T5 recorded eviscerated weight of $64.86 \%$ which was similar ( $p>0.05$ ) to the eviscerated weights of other birds on supplemental ascorbic acid but differed significantly $(p<0.05)$ from those on control. Other authors (Bonsembinate et al., 2002; Pisarski et al., 2003; Lohakare et al., 2004; Mbajiorgu et al., 2007; Ali et al., 2010) obtained similar results.

There was no significant $(p<0.05)$ difference in liver weight among the control birds and birds fed up to $300 \mathrm{ppm}$ supplemental dietary AA. However, there exist significant $(p<0.05)$ difference between the birds on control and those on 400 and 500ppm dietary supplementation. The weight of liver of birds on control was highest (1.92\%) while birds on 400 $(1.63 \%)$ and $500 p p m$ (1.64\%) ascorbic acid were lower. Konca et al. (2009) observed that up to $300 \mathrm{mg} / \mathrm{kg}$ AA supplementation did not improve liver weight. There were significant $(p<0.05)$ variations in the heart weight $(\%)$ of birds fed 100 and 200ppm AA supplemented diet but there was no significant $(p>0.05)$ difference between those on control and that on graded levels of AA. However, Sahin et al. (2003) earlier reported increased liver, heart, spleen and empty gizzard weight in birds on dietary ascorbic acid supplementation.

Birds fed 500ppm supplemental AA had significantly $(p<0.05)$ lower abdominal fat $(0.23)$ weight compared to birds on other diets and control. Birds on 200ppm had the highest (1.13) percent abdominal fat. This observation conformed to that of Kutlu (2001) and Sahin, et al. (2003) that dietary ascorbic acid supplementation decreased abdominal fat pad. Lack of significant variations $(p>0.05)$ in the values obtained for the control birds and the $A A$ supplemented diets up to 400ppm agreed with the observations of Ali et al. (2010) who did not obtain any significant difference $(p>0.05)$ in the abdominal 
fat of birds on 135ppm supplemental AA and the control (unsupplemented). Other studies (Fletcher and Cason, 1991; Celik and Ozturkcan, 2003 and Konca et al., 2009) also confirmed that AA supplementation had no effect on abdominal fat pad yield.

Table 3: Carcass characteristics, external offal and organ weights of broiler chickens fed diets supplemented with graded levels of ascorbic acid

\begin{tabular}{|l|l|l|l|l|l|l|l|}
\hline Parameters & T1 & T2 & T3 & T4 & T5 & T6 & SEM \\
\hline Live weight & $1.66^{\mathrm{b}}$ & $1.78^{\mathrm{ab}}$ & $1.75^{\mathrm{ab}}$ & $1.89^{\mathrm{a}}$ & $1.90^{\mathrm{a}}$ & $1.79^{\mathrm{ab}}$ & 0.04 \\
\hline Bled & 97.44 & 97.20 & 97.17 & 97.17 & 97.00 & 96.77 & 0.09 \\
\hline Defeathered & 91.62 & 90.70 & 91.53 & 91.49 & 91.78 & 91.13 & 0.16 \\
\hline Dressing \% & 74.70 & 76.58 & 75.20 & 75.79 & 75.59 & 74.77 & 0.29 \\
\hline Eviserated & $59.98^{\mathrm{b}}$ & $63.23^{\mathrm{ab}}$ & $63.39^{\mathrm{ab}}$ & $61.68^{\mathrm{ab}}$ & $64.86^{\mathrm{a}}$ & $62.38^{\mathrm{ab}}$ & 0.68 \\
\hline Thigh & 11.27 & 11.47 & 11.30 & 10.53 & 11.17 & 11.23 & 0.13 \\
\hline Drumstick & 11.09 & 10.65 & 10.65 & 11.25 & 11.08 & 11.30 & 0.12 \\
\hline Wings & 8.89 & 8.77 & 8.91 & 8.73 & 8.55 & 8.82 & 0.05 \\
\hline Breast & 18.15 & 19.72 & 20.63 & 20.16 & 21.27 & 19.24 & 0.45 \\
\hline Back & 14.39 & 14.08 & 14.35 & 14.45 & 14.21 & 13.65 & 0.12 \\
\hline Head & 2.79 & 2.53 & 2.61 & 3.06 & 2.48 & 2.79 & 0.09 \\
\hline Shank & 4.53 & 4.44 & 4.51 & 4.51 & 4.13 & 4.80 & 0.09 \\
\hline Neck & 5.13 & 5.45 & 5.73 & 4.95 & 5.53 & 5.32 & 0.11 \\
\hline Liver & $1.92^{\mathrm{a}}$ & $1.85^{\mathrm{ab}}$ & $1.78^{\mathrm{ab}}$ & $1.70^{\mathrm{ab}}$ & $1.63^{\mathrm{b}}$ & $1.64^{\mathrm{b}}$ & 0.05 \\
\hline Heart & $0.36^{\mathrm{ab}}$ & $0.32^{\mathrm{b}}$ & $0.42^{\mathrm{a}}$ & $0.35^{\mathrm{ab}}$ & $0.33^{\mathrm{ab}}$ & $0.36^{\mathrm{ab}}$ & 0.01 \\
\hline Gizzard & 2.43 & 2.37 & 2.38 & 2.33 & 2.37 & 2.32 & 0.02 \\
\hline Abdominal fat & $0.99^{\mathrm{a}}$ & $1.08^{\mathrm{a}}$ & $1.13^{\mathrm{a}}$ & $0.81^{\mathrm{a}}$ & $0.79^{\mathrm{a}}$ & $0.23^{\mathrm{b}}$ & 0.13 \\
\hline Intestine & 11.77 & 11.38 & 11.44 & 11.44 & 11.21 & 11.09 & 0.09 \\
\hline Spleen & 0.10 & 0.11 & 0.10 & 0.10 & 0.11 & 0.13 & 0.00 \\
\hline a, b: means in the sam & row with different superscripts are significantly different $(\mathrm{p}<0.05)$. & & \\
\hline
\end{tabular}

Table 4: Effect of graded ascorbic acid on the organoleptic properties of broiler meat

\begin{tabular}{|l|l|l|l|l|l|l|l|}
\hline Parameter & T1 & T2 & T3 & T4 & T5 & T6 & SEM \\
\hline Taste & 6.96 & 6.93 & 6.48 & 6.74 & 6.89 & 7.07 & 0.09 \\
\hline Flavor & 4.93 & 5.44 & 5.22 & 5.48 & 5.19 & 5.33 & 0.08 \\
\hline Color & $6.30^{\mathrm{b}}$ & $7.52^{\mathrm{a}}$ & $7.19^{\mathrm{ab}}$ & $7.19^{\mathrm{ab}}$ & $7.56^{\mathrm{a}}$ & $7.26^{\mathrm{ab}}$ & 0.19 \\
\hline Juiciness & 6.00 & 6.56 & 6.63 & 6.19 & 6.26 & 6.74 & 0.12 \\
\hline Tenderness & 6.74 & 6.78 & 7.00 & 7.00 & 6.52 & 7.26 & 0.11 \\
\hline $\begin{array}{l}\text { Overall } \\
\text { acceptability }\end{array}$ & 6.72 & 6.77 & 6.90 & 7.00 & 6.74 & 7.23 & 0.11 \\
\hline
\end{tabular}

Sensory attributes were measured on a 9-point hedonic scale, 9 is extremely desirable and 1, extremely undesirable. a,b,cmeans in the same row with similar superscripts are not significantly different $(p>0.05)$. 


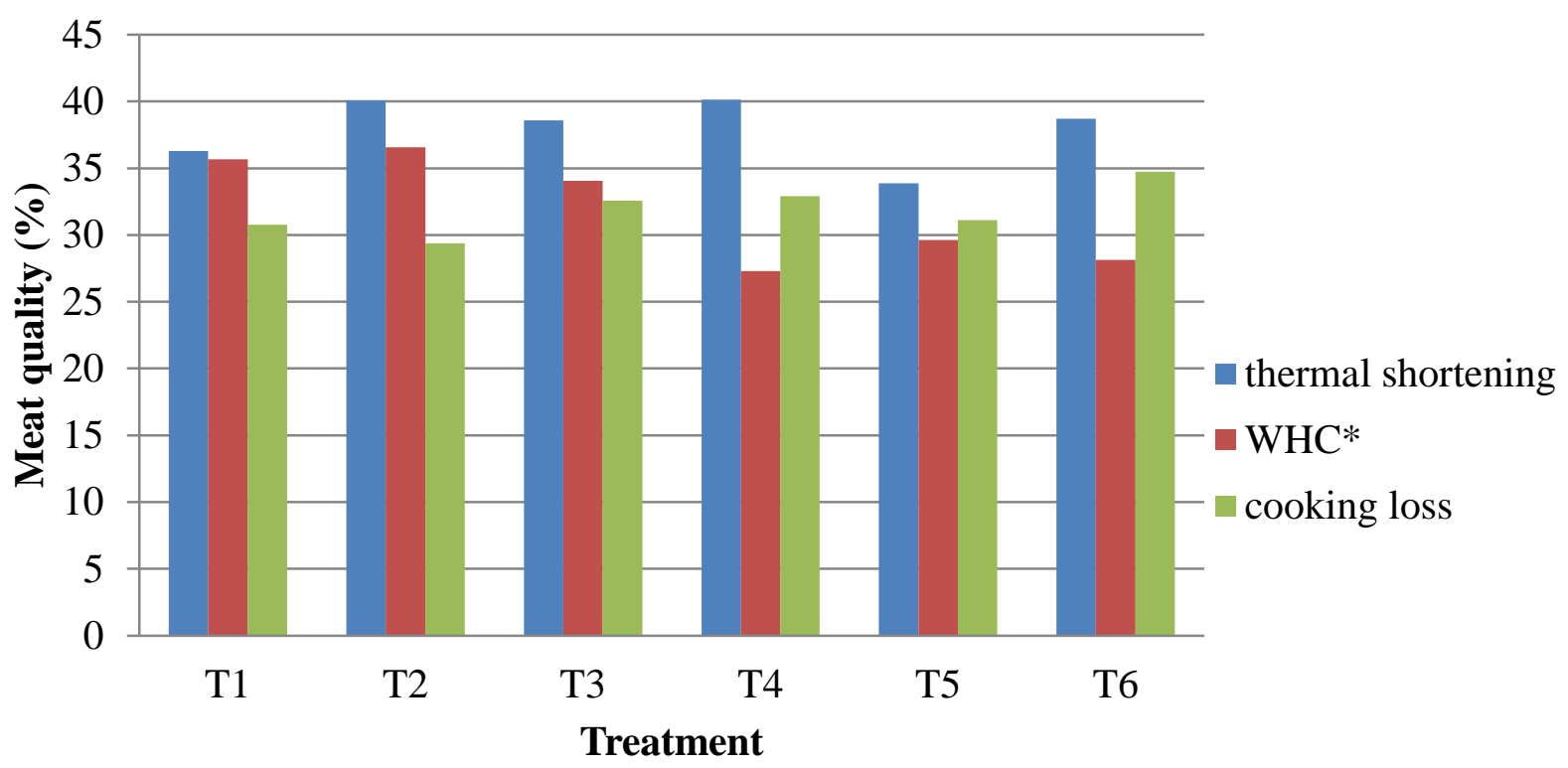

Fig. 2: Effect of graded levels of ascorbic acid on cooked meat quality of broiler birds

*water holding capacity of meat

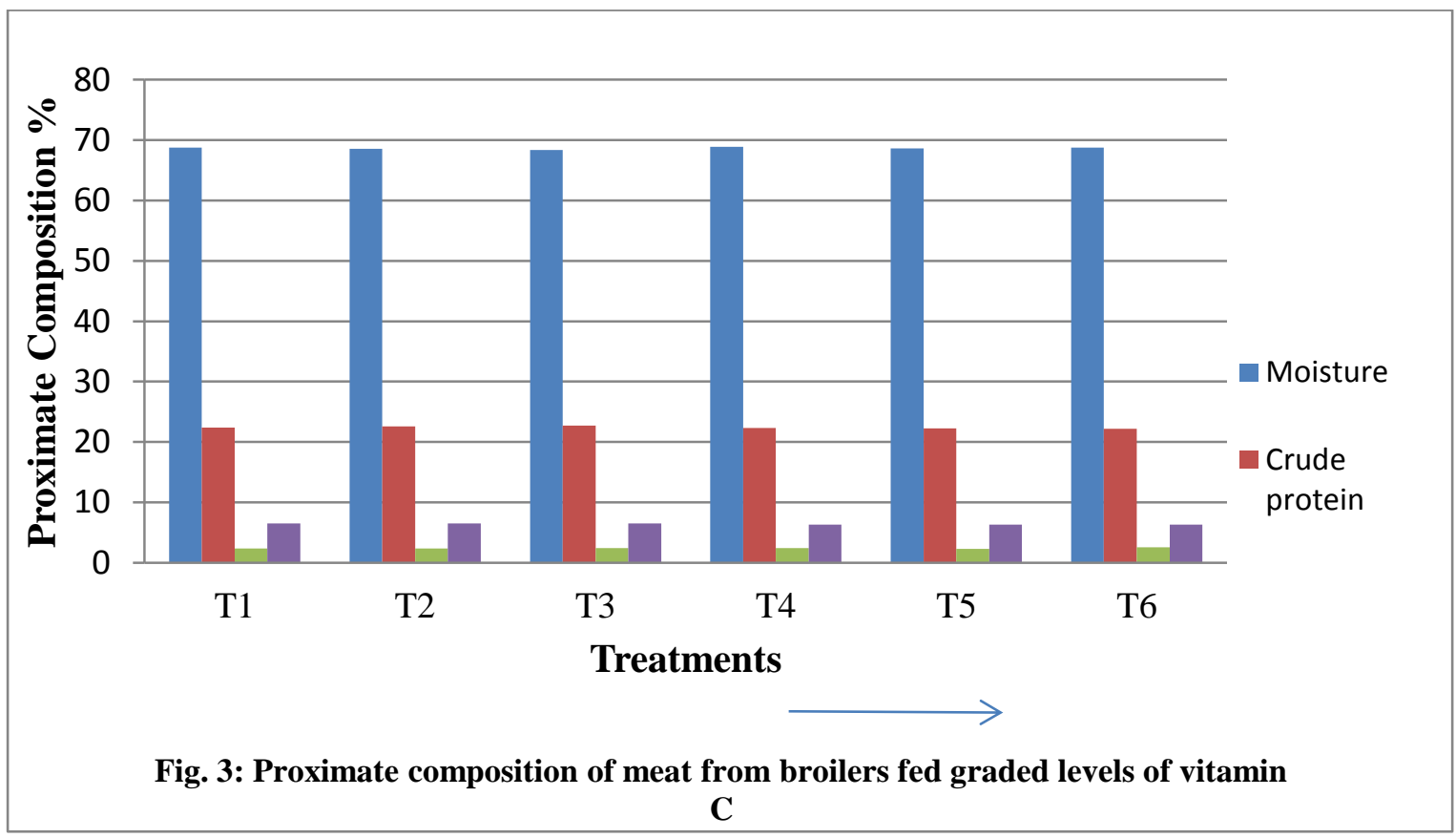


Agric. Biol. J. N. Am., 2013, 4(4): 485-495

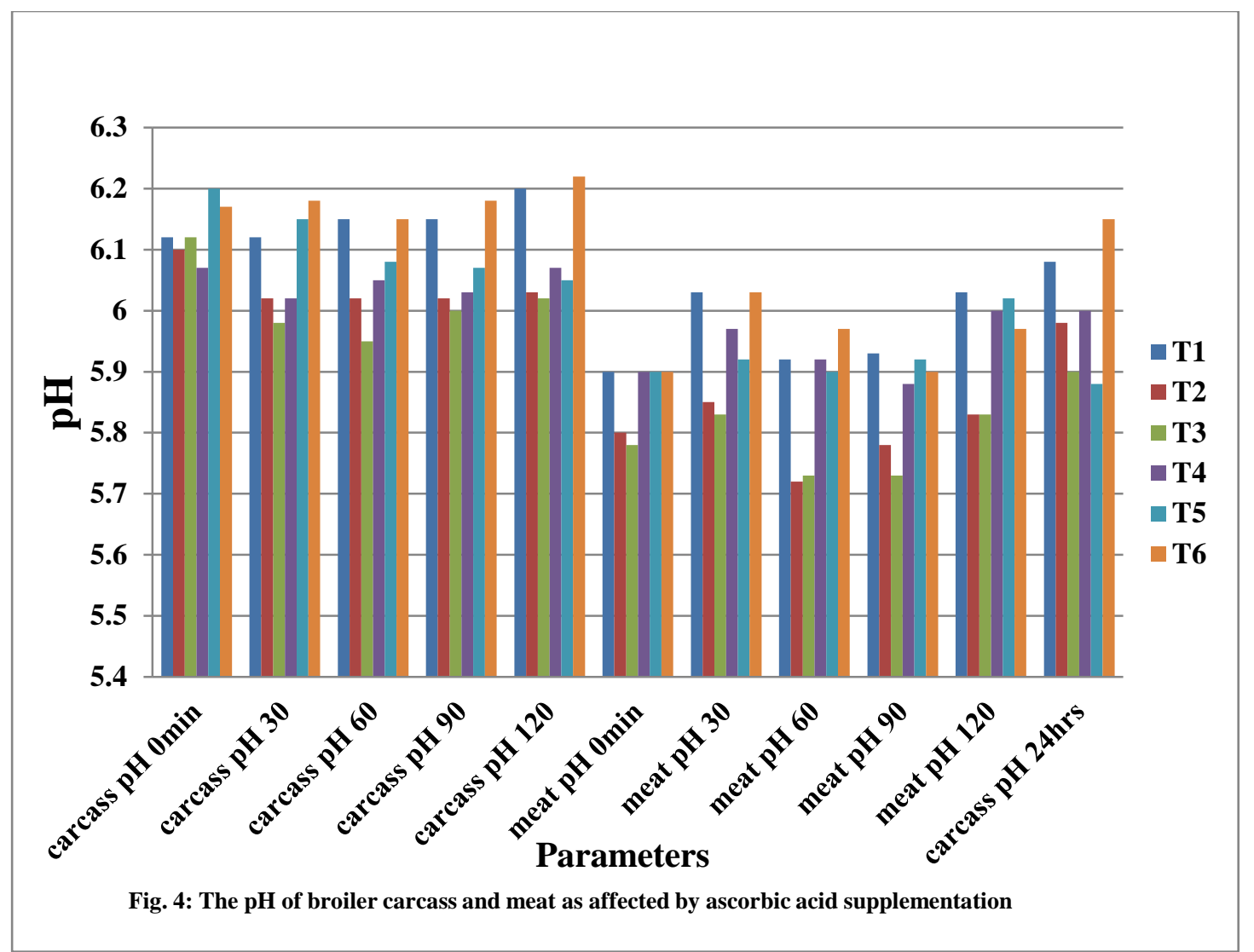

Organoleptic properties of meat from broiler birds fed graded levels of AA are shown in Table 4. Apart from meat color, other organoleptic parameters of meat from broiler birds and control were statistically similar $(p>0.05)$. The observation conformed to the findings of Chaves et al. (2008) on the effect of natural antioxidants on sensory characteristics of sirloins. Janz et al. (2007) also did not obtain any significant effect of different natural antioxidants on the sensory qualities of pig meat. In addition, Pisulewski (2005), surmised that dietary vitamin $\mathrm{C}$, was not as effective as dietary vitamin $\mathrm{E}$ and that exogenous addition of vitamin C i.e. its application to meat cuts, was ineffective in preserving meat quality.

Birds fed 400ppm level of ascorbic acid had the most preferred color score (7.76) though not statistically different from birds on 100ppm supplemental vitamin $\mathrm{C}$ but significantly different from the control. However, color score of birds fed graded levels of AA were not statistically different from one another. The difference in color observed in this work could be due to the ability of vitamin $\mathrm{C}$ in retarding meat color loss by reducing the rate of oxy-myoglobin oxidation to metmyoglobin. According to Djenane et al. (2003), rosemary and AA solution when sprayed on fresh beef steaks surface during refrigeration, reduced met-myoglobin formation and intense red coloration of meat; Chouliara et al. (2007) remarked that color parameter of fresh chicken breast meat did not vary by adding grape seed and bearberry extracts. Also, injection of beef with solution of sodium ascorbate was effective in improving color stability and extending the meat's retail display life (Wheeler et al., 1992). Other researchers (Nerlin et al., 2006; Camo et al., 2008) also reported evidence of natural antioxidant inhibiting off-odor formation and discoloration of meat.

Thermal shortening, water holding capacity, cooking loss and $\mathrm{pH}$ of broiler meat were not statistically different ( $p>0.05)$. The carcass and meat $\mathrm{pH}$ of birds across all dietary treatments had higher ultimate $\mathrm{pH}$ which declined gradually with time. This could be as a result of declining metabolic glycolysis in the meat as oxidative respiration ceases with passing time post-mortem. Swatland (2008) reported that there were implicit interrelationships between temperature and $\mathrm{pH}$ because glycolysis is exothermic and effects of $\mathrm{pH}$ very severe when a muscle is still near body temperature. 
The overall acceptability scores from all treatments ranged from 6.52 in control to 7.26 in meat of birds from T6 but the differences were not statistically different $(p>0.05)$. Expressible moisture (EM) is the percentage of total water in the meat that can be expressed by applied force. Generally, an increase in EM indicates a greater proportion of the water that is held more loosely and, thus, indicates a lower WHC (Honikel et al., 1996). The relationship between $\mathrm{pH}$ and EM has a long way to go with the acceptability parameters of meat which though not significantly different from the control in this work but all (birds fed graded levels of $A A$ ) had better score values than the control. The tenderness, juiciness, firmness, and appearance of meat have been reported (Anadon, 2002) to improve as the content of water in the muscle increases, leading to an improvement in quality and economical value. Vitamin C supplementation had no significant effect on the meat of treated birds and control on the overall acceptability scores for broiler meat.

The proximate (moisture, crude protein, ash and ether extract) composition of meat from broilers fed graded level of AA were similar $(p>0.05)$. Obtained values of ether extract of meat decreased progressively from those obtained from control (6.5) to (6.3) for meat of those fed 500ppm AA which was similar to the observation of Kutlu (2001) that dietary supplementation of AA decreases fat content in broiler.

\section{CONCLUSION}

Supplemental ascorbic acid was beneficial to the growth performance of broiler birds. At a relatively high dosage above 400ppm, it lowered the abdominal fat deposition and improved the color of chickens' meat. In this study no other demonstrable effect of the supplementation on performance, carcass characteristics, organ weights and physico-chemical attributes of broiler chickens was obtained.

\section{REFERENCES}

Ali, M. T., Howlider, M. A. R., Azad, A. K., and Rahman, M. S., 2010. Vitamin $C$ and electrolyte supplementation to support growth and meat yield of broilers in a hot humid environment. J. Bangladesh Agril. Univ. 8(1): 57-60.

Alisheikhor, A.M., 1980. The effect of different amounts of ascorbic acid on growth and accumulation of vitamin $\mathrm{C}$ in the tissue of chickens. Journal of Nutrition. 15: 471473.

Anadón, H. L. S. 2002. Biological, nutritional and processing factors affecting breast meat quality of broilers. 171f. Ph.D Thesis - Virginia Polytechnic Institute and State University. Available from: $<$ http://scholar.lib.vt.edu/theses/available/etd02212002-113821/unrestricted/Dissertation.pdf.

Assistat, 2012. ASSISTAT Version 7.6 beta., 2011. Website http://www.assistat.com. By Francisco de A. S. e Silva DEAG-CTRN-UFCG Updated on 05/14/2012

Awonrin, S. O. and J. A. Ayoade. 1992. Texture and eating quality of raw and thawed roasted turkey and chicken breast as influenced by age of birds and period of frozen storage. J. Food Service System 6: 214-255.

Blaha, J., Draslarova, J., and Kroesna, K., 2000. The effect of vitamin and electrolyte supplement on broiler performance under stress. Agricultural Tropical ET Subtropical. 33: 52-58.

Bolu, S. A., Malomo, G. A., and Olatunde, O.A., 2004. Response of cockerel chicks to different dietary sources of vitamin C. Tropical Journal of Animal Science. 7(2): 1-6

Bonsembiante, M., Chiericato, G. M. and Rizzi, C. 2002. Influence of different sodium bicarbonate dietary contents on the metabolic profile, productive performance and meat quality of broilers. Rivista-diAvicoltura, 71(1): 33-42. In: MS Thesis, Department of Poultry Science, BAU, Mymensingh, Bangladesh.

Camo, J., J. A. Beltran and P. Roncales. 2008. Extension of the display life of lamb with an anti oxidant active packaging did not affect eating satisfaction. Meat Science 57: 359- 363.

Celik, L. and Oztuurkcan, O., 2003. Effect of dietary supplemental L-carnitine and ascorbic acid on performance, carcass composition and plasma Lcarnitine concentration of broiler chicks reared under different temperature. Arch. Tieremahrung, 57: 27-38.

Chaves, A. V., K. Stanford, L. L. Gibson, T. A. McAllister and C. Benchaar. 2008. Effects of carvacrol and cinnamaldehyde on intake, rumen fermentation, growth performance, and carcass characteristics of growing lambs. Animal Feed Science and Technology 145: 396-408.

Chouliara, E. A. Karatapanis I. N., Savvaidis and M. G. Kontominas. 2007. Combined effect of oregano essential oil and modified atmosphere packaging on shelf-life extension of fresh chicken breast meat, stored at $4^{\circ} \mathrm{C}$. Food Microbiology 24:607-617.

Dale, N. M., and Fuller, L., 1980. Effect of diet composition on feed intake and growth of chicks under heat stress. 11. Constant vs. cycling temperature. Poultry Science. 59: $1434-441$.

Djenane, D. A. Sanchez-Escalante, J. A. Belra and P. Roncales. 2003. Extension of shelf-life of beaf steaks package in a modified atmosphere by treatment with 
rosemary and displayed under UV-free lighting. Meat Science 64: 417-426.

Faria D. E., Mazalli M. R., Salvador D., Junqueria O. M., Souza, P. A. (1999): Influence of different levels of vitamins $D$ and $C$ and age of laying hens on performance and egg quality in winter. Poultry Sci. Association 88th Annual Meeting, August 8-11, Springdale, Arkansas, 91.

Fletcher, D. L. and Cason, J. A., 1991. Influence of ascorbic acid on broiler shrink and processing yields. Poult. Sci., 70: $2191-2196$.

Halliwell, B. \& Gutteridge, J.M.C. 1989. Lipid peroxidation: a radical chain reaction. In: Free Radicals in Biology and Medicine, 2nd ed. Oxford University Press, New York, NY.

Horwitz, W. 1990. Official methods of analysis of association of official chemist. $15^{\text {th }} \mathrm{Ed}$.

AOAC, P. 1278.

Honikel, K. O., Kim, C. J. and Hamm, R. 1986. Sarcomere shortening of pre-rigor muscle and its influence on drip loss. Meat Science, 16: 267-282.

Janz, J. A. M., P. C. H. Morel, B. H. P. Wilkinson and R. W. Purchas. 2007. Preliminary investigation of the effects of low-level dietary inclusion of fragment essential oils and oleorensins on pig performance and pork quality. Meat Science 75:350-335.

Kafri, I. \& Cherry, J. A. 1984. Supplemental ascorbic acid and heat stress in broiler chicks. Poult. Sci. 63 (suppl.): 125.

Kassim, H., and I. Norziha. 1995. Effects of ascorbic acid (vitamin C) supplementation in layer and broiler diets in the tropics. Asian-australas. J. Anim. Sci. 8:607610.

Klasing, K. C. (1998) Comparative Avian Nutrition. University Press, Cambridge, UK.

Konca, Y., Kirkpinar, F., Mert, S., and Yurseven, S., 2009. Effect of dietary ascorbic acid supplementation of growth performance, carcass, bone quality and blood parameters in broilers during natural summer temperature. Asian Journal of Animal and Veterinary Advances, 4 (3): 139-147. Academic Journal Inc.

Kutlu, H. R. 2001. Influences of wet feeding and supplementation with ascorbic acid on performance and carcass composition of broiler chicks exposed to a high ambient. Arch Tierenrnabrungi, 54:127-139.

Lohakare, J. D., Chae, B. J., and Hahn, T. W. 2004. Effects of feeding methods (water vs. feed) of vitamin C on growth performance and carcass characteristics in broiler chickens. Asian Aust. J. Anim. Sci., 17: 11121117.
Lohakare, J. D., Ryu, M. H., Hahn, T.-W., Lee, J. K., and Chae, B. J. 2005. Effects of Supplemental Ascorbic Acid on the Performance and Immunity of Commercial Broilers. J. Appl. Poult. Res. 14:10-19. Poultry Science Association, Inc. JAPR: Research Report.

Mahendraker, N. S., V. S. Khabade and N. B. Dani (1988). Studies on the effects of fattening on carcass characteristics and quality of meat from Bannu-lamb. J. Food Sci. Techn. 25: 228-230

Majekodunmi, B. C., Sokunbi, O. A., Ogunwole, O. A., Lawal, T. T. and Oikeh, I. 2012. Impact of electrolytes and ascorbic acid water supplementation on the leukocyte profile of heat stressed broilers Proc. $17^{\text {th }}$ Ann. Conf. Animal Science Assoc. of Nigeria. International Conference Centre, Opposite Radio House, Area 8, Abuja, September 9-13 pp. 166-169. Eds. Akpa, G. N., Dairo, F. A. S., Bawa, G. S., Solomon, I. P., Amaefule, K. U., DedsnisigtAn:A. and Ladokun, A. O..

McDowell, L. R. 1989 Vitamins in animal nutrition: vitamin C, folacin. In: Comparative

Aspects to Human Nutrition (McDowell, L. R., ed.), pp. 298-322,365-387. Academic Press, London, UK.

Mckee, J. S., P. C. Harrison, and G. L. Riskowski. 1997. Effects of supplemental ascorbic acid on the energy conversion of broiler chicks during heat stress and feed withdrawal. Poult. Sci. 76:1278-1286.

Mowat, D. N. 1994. Organic chromium. A new nutrient for stressed animals. In: Biotechnology in the Feed Industry: Proceedings of Alltech's Tenth Annual Symposium (Lyons, T. P. \& Jacques, K. A., eds.), pp: 275-282. Nottingham University Press, Nottingham, UK.

Nerlin, C., L. Tovar, D. Djenane, J. Camo. J. Salafrance, J. A. Beltran, and P. Roncales. 2006. Stabilization of beef meat by a new active packaging containing natural antioxidant. Journal of Agriculture and Food Chemistry 52:5598-5605.

Njoku, P. C. 1986. Effect of dietary ascorbic acid supplementation on broiler chickens in a tropical environment. Animal Feed Science and Technology, Elsevier Publisher, Netherlands, 16: 17-24

Njoku, P. C., Whitehead, C.C., and Mitchell, M.A., 1990. Heat stress and vitamin $C$ effect on the production characteristics of chicken. Symposium on ascorbic acid in domestic animals. Kartause Ittingen.

Ogunwole, O. A., Oikeh, I. Olowe, T. O., Omotoso, R. R. and Oso, Y. A. A. 2012. Blood profile of broiler starter chickens as affected by diets supplemented with graded levels of ascorbic acid. Proc. $17^{\text {th }}$ Ann. Conf. Animal Science Assoc. of Nigeria. International Conference Centre, Opposite Radio House, Area 8, Abuja, September 9-13 pp. 203-206. Eds. Akpa, G. N., 
Dairo, F. A. S., Bawa, G. S., Solomon, I. P., Amaefule, K. U., Odunsi, A. A. and Ladokun, A. O.

Ogunwole, O. A., B. C. Majekodunmi, T. O. Olowe, and Olumide, M. D. 2013. Meat quality and bone characteristics of broiler chickens fed diets supplemented with graded levels of ascorbic acid. Proc. $38^{\text {th }}$ Conf. Nig. Soc. Anim. Prod. Rivers State Univ. of Science and Tech. 17-20 March, pp. 774-776. Eds. B. M. Oruwari, J. P. Alawa, U. I. Oji, O. J. Owen and O. S. George.

Oluyemi, J. A and F. A. Roberts. 2000. Poultry production in the warm wet climate. 1st Edition Macmillan

Press, Ltd, Nigeria.

Omojola, A. B. and Adesehinwa, A. O. K. 2007. Performance and Carcass Characteristics of Broiler Chicken fed diets supplemented with graded level of Roxazyme

$\mathrm{G}^{\mathrm{R}}$. International J. of Poultry Science 6 (5) 335-339

Onu P. N. 2009. Growth performance, carcass characteristics and economic benefits of supplemental ascorbic acid on broiler starters exposed to heat stress. ARPN Journal of Agricultural and Biological Science vol. 4, No. 5, September 2009. (C2006-2009 Asian Research Publishing Network (ARPN). www.arpnjournals.com

Oruseibio, S.M., and Alu, E. U. 2006. Responses of broiler birds to supplementation of Ascorbic acid vitamin C. Nigeria Poultry Science Journal. 4: 12-15

Pardue, S. L., and J. P. Thaxton. 1986. Ascorbic acid in poultry: A review. World Poult. Sci. J. 42:107-123.

Pardue, S. L., Thaxton, J. P. and Brake, J. 1985. Role of ascorbic acid in chicks exposed to high environmental temperature, Journal of Applied Physiology, 58(5): $1511-1516$

Pisarski, R.K., Malec, H., Pijarska, I. and Lechowski, J. 2003. The effect of ascorbic acid on the chemical composition and fatty acid profile of broiler chicken's breast muscle. Roczniki Naukowe Zootechniki, 30(1): 113-119. In: MS Thesis, Department of Poultry Science, BAU, Mymensingh, Bangladesh.

Pisulewski M., Pawel. 2005. Nutritional potential for improving meat quality in poultry. Animal Science Papers and Reports vol. 23(2005) no. 4:303-315. Institute of Genetics and Animal Breeding, Jastrzebiec, Poland.

Puron, D., Santamaria, P. and Segura, J. C. 1994. Effect of Sodium Bicarbonate, Acetylsalicylic and Ascorbic acid on broiler performance in a tropical environment, Journal of Applied Poultry Research, 3: 141-145

Raja, A. Q., and Qureshi, A. 2000. Effectiveness of supplementation of vitamin $\mathrm{C}$ in baler feed hot season. Pakistan Veterinary Journal. 20: 100-104.
Sabah, E. M. K., Mohammed, A. M. M., and Abdel, G. S. M. 2008. Effect of feed restriction and ascorbic acid supplementation on performance of broiler chicks reared under heat stress. Research Journal of Animal and Veterinary Sciences. 3: 1-8.

Sahin, K., and O. Kucuk. 2001. Effects of vitamin C and vitamin $\mathrm{E}$ on performance, digestion of nutrients, and carcass characteristics of Japanese quails reared under chronic heat stress $\left(34^{0} \mathrm{C}\right)$. J. Anim. Physiol. Anim. Nutr. 85:335-342.

Sahin, K., Onderci, M., Sahin, N., Gursu, M. F., and Kucuk, O. 2003. Dietary Vitamin C and Folic Acid Supplementation Ameliorates the Detrimental Effects of Heat Stress in Japanese Quail. J. Nutr. 133: 18821886, (C) 2003 American Society for Nutritional Sciences.

Sahin, K., Sahin, N., Onderci, M., Yaralıoglu, S. \& Kucuk, O. 2001. Protective role of supplemental vitamin $\mathrm{E}$ on lipid peroxidation, vitamins $E, A$ and some mineral concentrations of broilers reared under heat stress. Vet. Med. Czech. 46: 140-144.

Sifri, M., F. H. Kratzer, and L. C. Norris. 1977. Lack of effect of ascorbic and citric acids on calcium metabolism of chickens. J. Nutr. 107:1484-1492.

Sobayo, R. A., Oguntona, E. B., Osinowo, O. A., Eruvbetine, D., Bamgbose, A. M., Adeyemi, O. A., Lomola, A. O., Okeke, E. N., and Usman, J. M. 2008. Effects of Ascorbic acid supplementation on the performance indices of starter pullets in a humid environment. Proceeding of the $33^{\text {rd }}$ Annual conference of Nigerian society for Animal production. pp. 428-430.

Sosnowka - Czajka E., Skomorucha I., Herbut E. (2003): Effect of supplemental vitamin $\mathrm{C}$ and cold stress on performance of broiler chickens. Ann. Anim. Sci., Suppl., 2: 227 - 230.

Sosnowka - Czajka, E., Skomorucha, I., Herbut, E., 2005. Effect of dietary vitamin supplements on productivity and physiological parameters of broiler chickens exposed to elevated ambient temperature. ISAH Vol 2. pp. 111-114. Warsaw, Poland.

Suzuki, A., Kaima, N.,Ikeuchi, Y., (1991). Carcass composition and meat quality of Chinese

Purebred and European $X$ Chinese crossbred pigs. Meat Sci. 29:31-41

Swatland, H. J. 2008. How pH causes paleness or darkness in chicken breast meat. Meat Science. 80: 396-400.

Sykes, A. H. (1978) Vitamin C for poultry: some recent research. In: Proceedings of the Roche Symposium London, pp. 5-15. 
Sykes, A.H. 1977. Nutrition-environment interaction in poultry, in Nutrition and the Climatic Environment, Page 17-31, Butterworth Group, Nottingham, UK

Takahashi K., Akiba Y. and Horiguchi, M. 1991. Effects of supplemental ascorbic acid on performance, organ weight and plasma cholesterol concentration in broiler treated with propylthiouracil. British Poultry Science 32 (3): 545-554

Vathana, S., Kang, K., Loan, C. P., Thinggaard, G., Kabasa, J. D., U. ter Meulen, 2002. Effect of Vitamin C Supplementation on Performance of Broiler Chickens in Cambodia. Conference on International Agricultural Research for Development. Deutscher Tropentag,Witzenhausen.
Villar-Patiño, G., Díaz-Cruz, A., Avila-González, E., Guinzberg, R., Pablos, J.L., Piña, E., 2002. Effects of dietary supplementation with vitamin $\mathrm{C}$ or vitamin $\mathrm{E}$ on cardiac lipid peroxidation and growth performance in broilers at risk of developing ascites syndrome. Am. J. Vet Res. 63(5):673-6. [PubMed - indexed for MEDLINE]

Wheeler, T.L., J.D. Crouse and M. Koohmaraie. 1992. The effect of postmortem time of injection and freezing on the effectiveness of calcium chloride for improving beef tenderness. J. Anim. Sci., 70: 3451-3457.

Yanaka, M. and Okumura, J. 1982. Influence of ascorbic acid on the adverse effect of feeding a diet containing excess tyrosine to chicks. British Poultry Science 23 (3): 239-245 